\title{
Vegetation Structure and Floristic Features of Al Rayn Region, Saudi Arabia
}

\author{
Nurah M Alzamel* \\ College of Science and Humanities, Shaqra University, Saudi Arabia
}

\begin{abstract}
This is the first study, so far, to monitor the plant species composition and the vegetation cover of different communities occurring in Al Rayn city. This study estimates the vegetation of Al Rayn region of Saudi. A maximum of 19 plant species belonging to 13 different plant families were collected and identified to distribute among four plant communities namely: Rhyzastricta, Pulicariacrispa, Citrulluscolocynthis and Acacia ehrenbergiana. The most common plant families were Asteraceae (3 species). The main factors controlling the plant presence were soil texture, $\mathrm{pH}, \mathrm{CaCO}, \mathrm{Na}, \mathrm{Mg}, \mathrm{Ca}, \mathrm{Cl}$, $\mathrm{EC}$ and the content of organic matter. The majority of the registered species in this survey were perennials with 12 of the total recorded species (63.2\%), followed Annuals by seven species (36.8\%).
\end{abstract}

\section{Keywords}

Vegetation, Flora, Al Rayn, Saudi Arabia

\section{Introduction}

Kingdom of Saudi Arabia is the largest arid land in the Arabian Peninsula, with an area of about $2,250,000 \mathrm{~km}^{2}$. It is approximately located between latitude 15ㅇ 450' $\mathrm{N}$ and 340 $350^{\prime} \mathrm{N}$ and between longitudes 340 400' $\mathrm{E}$ and 550 450' $\mathrm{E}$ (Al-Shareef 2002 [1]; Miller and Cope 1996) [2]. Saudi Arabia is characterized by the diversity of its topography because of its large land forming the bulk of the Arabian Peninsula. There is different topography, as there are the mountains, valleys, sand dunes, plateaus, and plains (Al-Nafie 2004) [3]. These variations are reflected in the country distinctive ecological habitats, vegetation zones and consequently rich flora. It is endowed with a wide range of ecosystems and species diversity, especially in the southwestern region (Fadl, et al. 2015) [4].

The flora of Saudi Arabia has been extensively studied (Zohary 1957) [5]; the most important studies is given by (Migahid1978) [6] 'Flora of Saudi Arabia' and published for four times, the last edition was published in 1996. Furthermore, three volumes about 'Flora of the Kingdom of Saudi Arabia Illustrated' was written by (Chaudhary 2001) [7]. Moreover, a book was written by (Chaudhary and Al-Jowaid 2013) [8] titled Vegetation of the Kingdom of Saudi Arabia. Large number of articles have discussed this topic such as Contribution to the Flora of Saudi Arabia: Hail Region by (AlTurki and Al-Olayan 2003) [9]; A floristic account on Raudhat Khraim Central province, Saudi Arabia by (Al-Farhan 2011) [10] and Diversity of Perennial Plants at Ibex Reserve in Saudi Arabia by (Al-Khamis, et al. 2012) [11]. According to (Mossa, et al. 1987) [12], the Kingdom of Saudi Arabia is gifted with a wide range of flora, consisting of a large number of medicinal herbs, shrubs and trees.

Flora of Saudi Arabia includes about 2285 plant species. Approximately 656 species subsist in small populations while, 500 species are coexisting in limited areas. Moreover, around 100 species have been recorded as endangered (Al-Farhan 2011) [10]. These records not only furnish an important baseline for the floristic elements but also give an authoritative knowledge about the distribution of these species. Raudhas vegetation in the central part of Saudi Arabia was analyzed by Shaltout and Madi (1996) [13]. The floristic account of Raudhat Khuraim in the central province was also reported by Al-Farhan (2011) [10]. In addition, comparative ecological studies were also conducted by Al-Ghanim (2002) [14] on the natural vegetation in the Riyadh region. However, few studies have dealt with vegetation analysis and species diversity Saudi Arabia.

*Corresponding author: Nurah M Alzamel, College of Science and Humanities, Shaqra University, Saudi Arabia

Accepted: July 05, 2021

Published online: July 07, 2021

Citation: Alzamel NM (2021) Vegetation Structure and Floristic Features of Al Rayn Region, Saudi Arabia. Adv Environ Stud 5(2):436-442 
The aim of the current research is to study vegetation structure and some environmental conditions which controlling their distribution in fenced sites of Al Rayn city. Beside, this study may consider the first monitoring of vegetation cover of this version area. Furthermore, the life forms, vegetation types and choro types of the gathering species taken into seeing.

\section{Materials and Methods}

\section{Study area}

Al Rayn city is located in the central region of Saudi Arabiaat

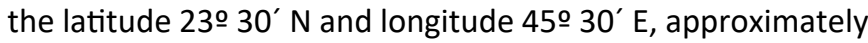
$759 \mathrm{~m}$ above sea level, with an area of $240 \mathrm{~km}^{2}$ (Figure 1). It is situated about $150 \mathrm{~km}$ south-west of Al Riyadh Province and $60 \mathrm{~km}$ south of El-Qwaiaea City. It has two different geological regions; located on the Arabian Shield sector contained of (Metamorphic, plutonic and volcanic rocks) at the west and the other is located in the sedimentary sector (the Arabian Shelf) at the east (Al-Nafie 2008) [15].

\section{Climate}

The natural conditions and geographical position of the central region (Al Rayn region) of Saudi Arabia is distinctive region, as it occupies a key position between East and west of Arabian Peninsula. The climate of the study area changes drastically from hot dry in low lands to rainy cold in high mountains is characterized by high temperatures especially from June to August when the temperature can exceed than $41.1 \stackrel{\circ}{ } \mathrm{C}$, while in the winter months from December to February the temperature is not greater than $20{ }^{\circ} \mathrm{C}$. The general climate in the study area is hot summer and mild to cold winter. The rainfall is very low with an average of less than $50 \mathrm{~mm} /$ month, and most of the rain falls during spring with almost no rain in the summer. The wind is usually laden with dust from upwind desert areas. In the summer, the humidity is lower than in the winter (Table 1).
Average mean maximum temperatures for the coolest months, December and January, are reached to $21.4{ }^{\circ} \mathrm{C}$ and $20.1 \stackrel{ }{\circ} \mathrm{C}$, respectively, while the mean minimum temperatures ranged from $8.4{ }^{\circ} \mathrm{C}$ in December and $7.4{ }^{\circ} \mathrm{C}$ in January (Figure 1). Summers, from June to August, are hot, with day time temperatures in the shade did not exceed 42.7 으. The mean maximum temperature ranged from 41.1 으 $\mathrm{C}$ in June and $42.7{ }^{\circ} \mathrm{C}$ in august, while mean minimum temperature ranged from $26.6{ }^{\circ} \mathrm{C}$ to $24.5 \stackrel{\circ}{ } \mathrm{C}$, respectively. The high percentage of relative humidity is recorded in December to February at the maximum in January (73\%). In the summer, relative humidity reached $37 \%$ in June and rose to $51 \%$ in August (Figure 2).

Precipitation is also low throughout the study area (Figures 3 and Figure 4). It is noted that the rainy season starts in October and increases in quantity in the following months until April to stop mostly from May, and there is a significant difference in the distribution of rainfall, the month of March is the rainiest rate of about $62.1 \mathrm{~mm}$. The mean annual precipitation decreased to reach less than $233.4 \mathrm{~mm}$ in the last year 2018 (Figure 5).

\section{Inventory of plant species}

A comprehensive survey of all plants (perennials and annuals), developed and identified according of (Collenette 1990 [16]; Migahid 1996) [17]. Herbarium specimens were saved in the herbarium of the Biology Department, Science

Table 1: Average of climate records for 10 years (2009 - 2018) in Al Rayn area (Source: Saudi General Authority of Meteorology and Environmental Protection).

\begin{tabular}{|l|c|c|}
\hline Climate variable & Range & Mean \\
\hline Max air temperature ( $\left.{ }^{\circ} \mathrm{C}\right)$ & $34.7-35.8$ & 35.2 \\
\hline Min air temperature $\left({ }^{\circ} \mathrm{C}\right)$ & $13.7-16.2$ & 15.0 \\
\hline Rainfall (mm/ month) & $0.02-42.4$ & 21.3 \\
\hline Relative humidity (\%) & $45.3-61.1$ & 59.2 \\
\hline Wind speed (km/ h) & $4.6-16.8$ & 10.7 \\
\hline
\end{tabular}

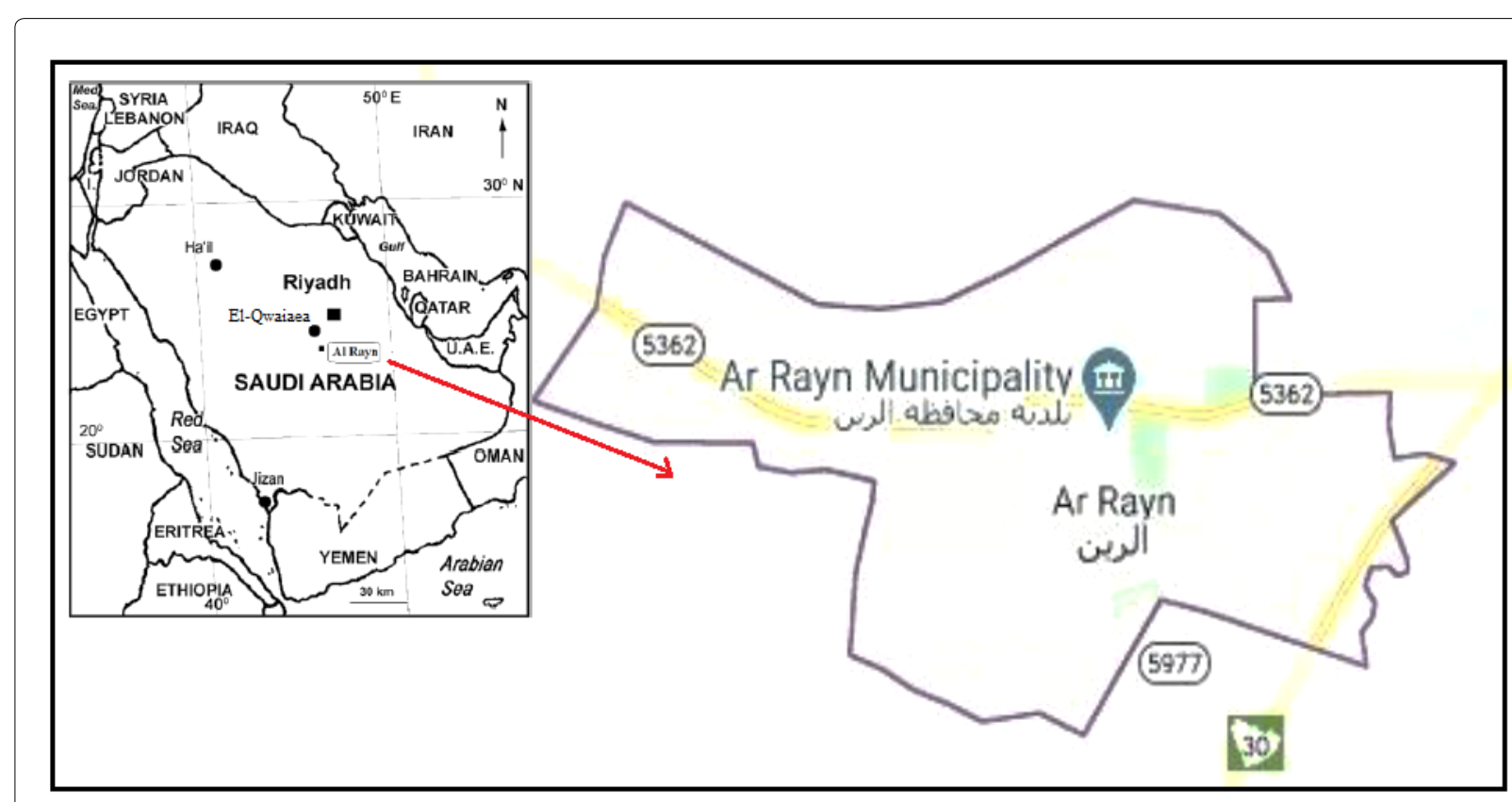

Figure 1: Map of Saudi Arabia showing the study area. 


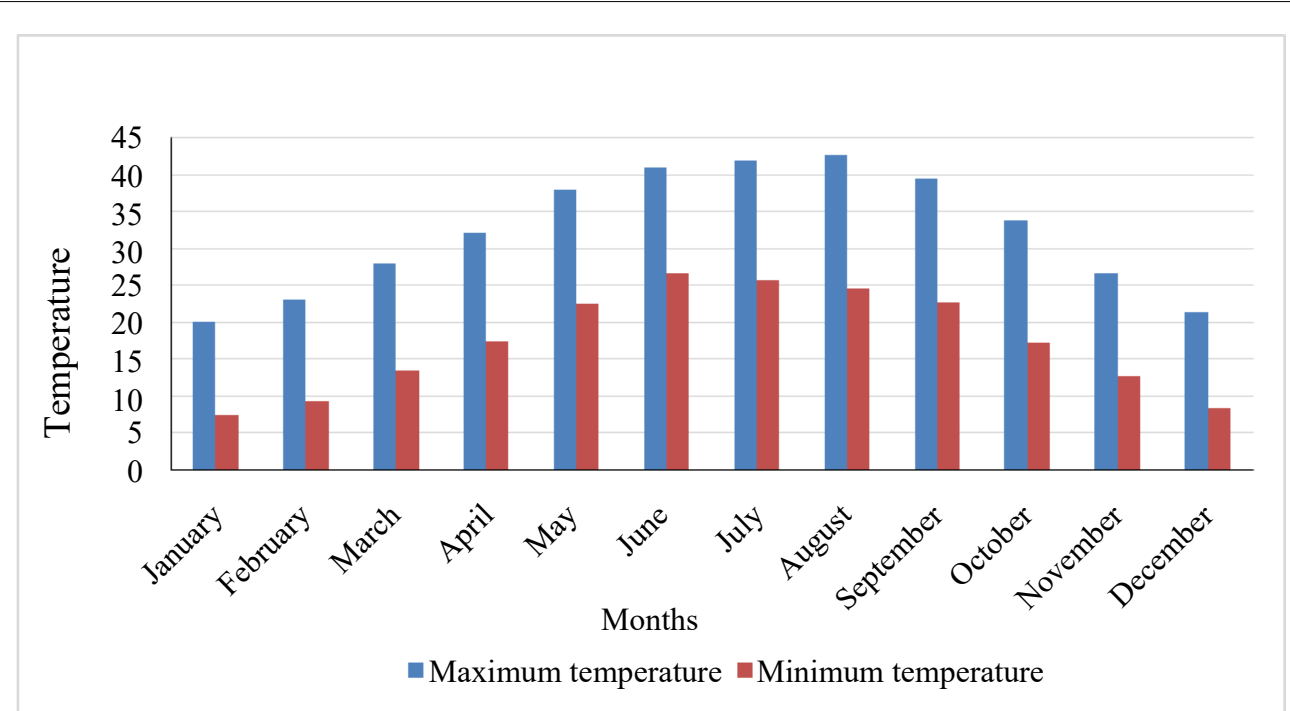

Figure 2: Monthly mean minimum and maximum temperature in Al Rayn area (average for 10 years (2009 - 2018).

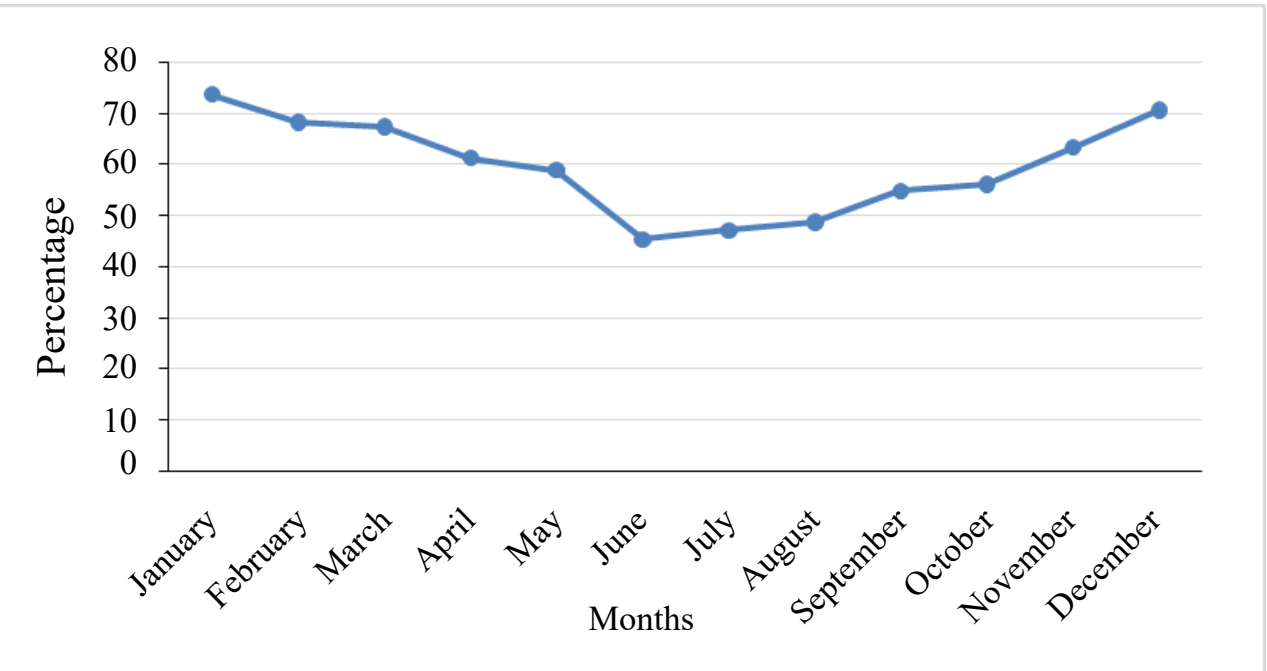

Figure 3: Mean relative humidity in Al Rayn area.

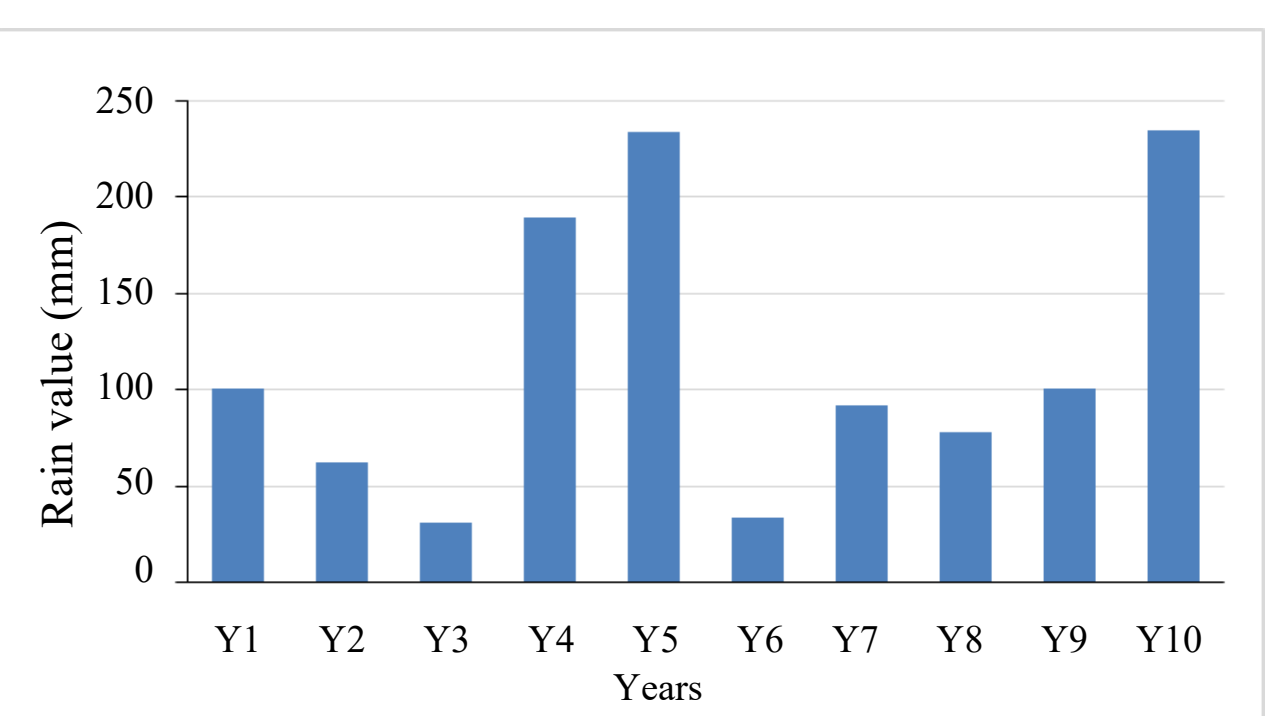

Figure 4: Mean annual rainfall $(\mathrm{mm})$ in last ten years inAl Rayn area. 


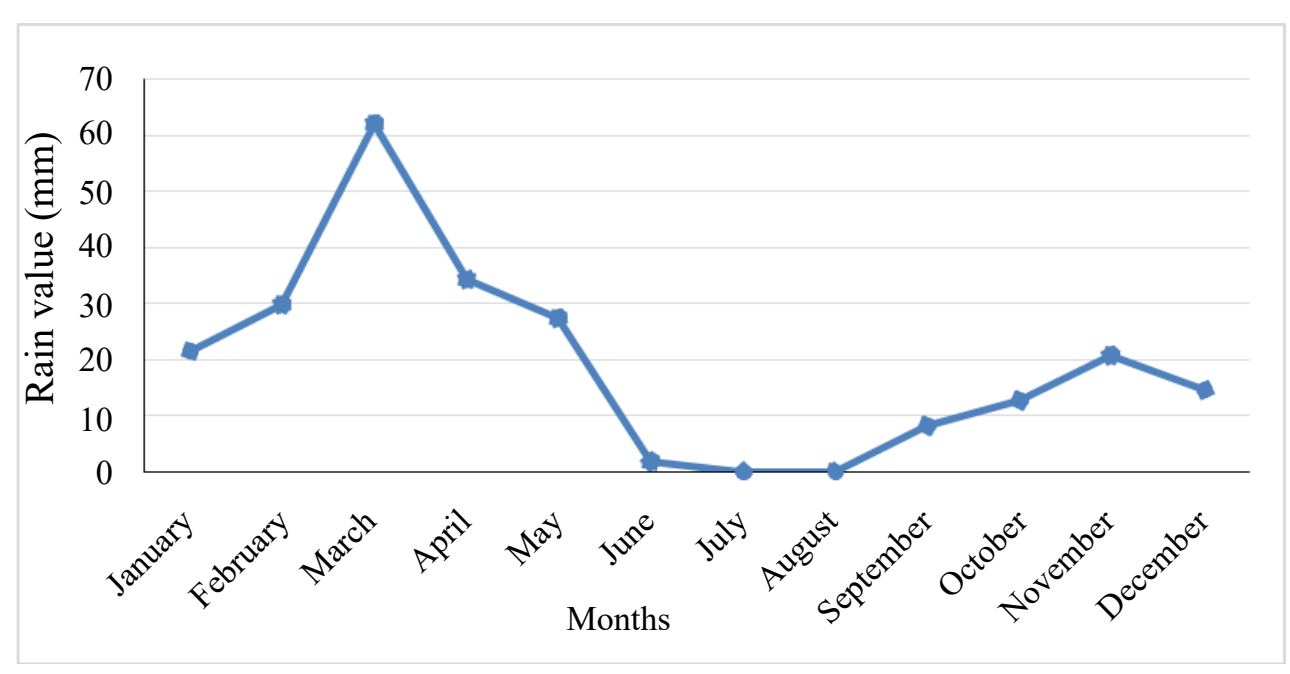

Figure 5: Average monthly rainfall of last ten years in Al Rayn area.

College. The current study was carried out during the period 2017-2018. According to the considerable variations in plant cover, more than 12 stands were chosen. These stands represent more than $50 \%$ of the total area of Al Rayn area. The studied species were rated according to BraunBlonquet (1965) [18]. The characteristics of vegetation cover was identified and divided into vegetal communities through some plant measurements (frequency, density and coverage) and then calculate the relative importance of each species in a number of selected environmental sites through exploratory visits taking into consideration that the sites are representative of plant communities using the intersection method Line-intercept, where a 100-meter metric bar is provided at the site and the metric band is divided into equal sections of $25 \mathrm{~m}$. Life forms of the recorded species were identified after (Raunkiaer 1937) [19], as adapted by (Govaerts, et al. 2000) [20]. Phytogeographical affinities were recognized after (Zohary 1957 [5]; Wickens 1978) [21].

\section{Soil analysis}

Three soil samples were collected from each stand at a depth of $50 \mathrm{~cm}$ and mixed together to form a composite sample. The hydrometer method was used to determine the soil texture (Day 1965). Total organic matter was determined based on "Loss on Ignition" method at 550 ㄷ. Soil water extract was prepared (1:5) by dissolving $100 \mathrm{~g}$ air-dried soil in $500 \mathrm{ml}$ distilled water for estimation of $\mathrm{pH}$ and electrical conductivity (EC). Soil nutrient elements ( $\mathrm{Ca}, \mathrm{K}, \mathrm{Na}, \mathrm{Mg}$, $\mathrm{HCO}_{3}, \mathrm{CaCO}_{3}$ and $\mathrm{Cl}$ ) were measured following the methods described by (Allen 1989 [22]; Ryan, et al. 2001) [23]. All the edaphic variables were assessed statically using COSTAT software for Windows version (4.6) and One-way analysis of variance was applied to assess the significance of variations using SPSS for windows version (25).

\section{Results}

\section{Floristic analysis}

Al Rayn city represented by nineteen species related to thirteen families (Table 2). Asteraceae ( 3 species $=15.8 \%$ ).
Fabaceae Brassicaceae, Apocynaceae and Poaceae were represented by $10.5 \%$ ( 2 species). Eight families were represented by one species (Table 2 ). In respect to vegetation type, the majority of the registered species in this survey were perennials with 12 of the total recorded species (63.2\%), followed by annuals the with 7 species (36.8\%).

According to the classification of Raunkiaer four life forms were recorded, themostnumerouslife form waschamaephytes $(47.4 \%=9$ species $)$, followed by hemicryptophytes ( 5 species $=26.3 \%$ ), phanerophytes ( 3 species $=15.8 \%$ ) and therophytes ( 2 species $=10.5 \%$ ) (Tables 2, Figure 6). Phytogeographically, the listed species were classified into two groups; monoregional and bioregional. About of 12 species (63.2\%) were monoregional. monoregional species fall under three affinities; Saharo-Arabian (6 species $=31.6 \%$ ), both Tropical and Cosmopolitan ( 3 species $=15.8 \%$ ). Biregional elements were represented by 7 species comprising $36.8 \%$ of recorded species. Sahel-Somalia represented by 2 species (10.5\%). The rest of chorotypes were represented by one species (5.3\%) for more details see (Tables 2, Figure 7).

\section{Vegetation analysis}

The different types of plant communities in the study area reflect the variation in environmental conditions such as habitat, altitudinal factors and moisture availability. Therefore, four plant communities are identified and arranged according to their dominant species in Al Rayn city (Table 1). Four communities are defined using the elucidation distance cluster analyses between groups of vegetation (Figure 8).

Rhyzastricta community: was characterized by ten plant species (sevenperennials and three annuals). Rhazyastrica was the highest with value (103) and the co-dominated one was Pulicariacrispa with value (84.3). The annual species were Chenopodiumglaucum, Aegilopus peregrina and Fagonia chweinfurthii (Table 2).This community is widely spread on wide hard sandy soil among low rocky hills.

Pulicariacrispa community: was characterized by eleven plant species (seven perennials and four annuals). Pulicariacrispa was the highest with value (103) and the co- 
Table 2: Floristic composition and mean of the importance values (out of 300) of the recorded species in the four plant communities of the study area. TR: Tropical, SH-SM: Sahel-Somalia Masai, SA-SM: Saharo Arabian-Somalia Masai, SA-IT: Saharo Arabian-IranoTuranian, SA: Saharo Arabian, MED-IT:Mediterranean-IranoTuranian, MED-IT: Mediterranean-IranoTuranian, IT: IranoTuranian, Eu -Med: Euro SiberianMediterranean, COSM: Cosmopolitan.

\begin{tabular}{|c|c|c|c|c|c|c|c|c|}
\hline Families & Species & Life forms & Chorotype & Habit & I & II & III & IV \\
\hline \multirow{2}{*}{ Fabaceae } & Acacia ehrenbergiana Hayne & $\mathrm{Ph}$ & SA & Per & 0 & 0 & 23.4 & 145.6 \\
\hline & Senna italica Mill. & $\mathrm{Ch}$ & SH-SM & Per & 23.4 & 84.3 & 0 & 0 \\
\hline \multirow{3}{*}{ Asteraceae } & Artemisia inculta Delile & $\mathrm{Ch}$ & SA & Per & 10.2 & 23.9 & 0 & 0 \\
\hline & Pulicariacrispa (Forssk.) Oliv. & $\mathrm{Ch}$ & TR & Per & 84.3 & 103.0 & 9.2 & 60.2 \\
\hline & Xanthium pungens Wallr. & $\mathrm{Ch}$ & TR & Ann & - & - & + & - \\
\hline \multirow{2}{*}{ Apocynaceae } & Calotropisprocera (Aiton) W. T. Aiton & $\mathrm{Ph}$ & SH-SM & Per & 0 & 0 & 84.3 & 17.4 \\
\hline & RhazyastrictaDecne & $\mathrm{Ch}$ & SA & Per & 103.0 & 46.1 & 23.9 & 13.4 \\
\hline \multirow{2}{*}{ Brassicaceae } & Erysimumrepandum L. & Th & SA & Ann & - & + & + & - \\
\hline & Zillaspinosa L. & $\mathrm{Ch}$ & SA & Per & 9.2 & 9.2 & 10.2 & \\
\hline Chenopodiaceae & Chenopodiumglaucum $\mathrm{L}$. & $\mathrm{He}$ & EU-MED & Ann & + & - & + & - \\
\hline Cucurbitaceae & CitrulluscolocynthisSchrad. & $\mathrm{He}$ & SR & Per & 0 & 0 & 103.0 & 0 \\
\hline Lamiaceae & $\begin{array}{l}\text { Teucriumpolium(Decne) Asch. } \\
\text { \&Schweif. Per. }\end{array}$ & $\mathrm{Ch}$ & ME-IT & Per & 46.1 & 23.4 & 0 & 0 \\
\hline Papaveraceae & Argemoneochroleuca Sweet & $\mathrm{Ch}$ & cosm & Ann & - & + & - & - \\
\hline \multirow[t]{2}{*}{ Poaceae } & $\begin{array}{l}\text { Aegilopusperegrina (Hack.) Maire } \\
\text { \&Weiller }\end{array}$ & $\mathrm{He}$ & SA-SI & Ann & + & + & - & - \\
\hline & Stipagrostisdrarii(Täckh.) De Winter. & $\mathrm{He}$ & SA-IT & Per & 0 & 0 & 0 & 63.4 \\
\hline Portulacaceae & Portalacaoleracea L. & Th & cosm & Per & 23.9 & 10.2 & 0 & 0 \\
\hline Rhamnaceae & Ziziphusnummularia (Burm.) f. & $\mathrm{Ph}$ & SA-SI-IT & Perr & 0 & 0 & 46.1 & 0 \\
\hline Solanaceae & Solanumnigrum $\mathrm{L}$. & $\mathrm{Ch}$ & cosm & Ann & - & - & - & + \\
\hline Zygophyllaceae & Fagoniaschweinfurthii Hadidi & $\mathrm{H}$ & SA & Ann & + & + & - & - \\
\hline
\end{tabular}

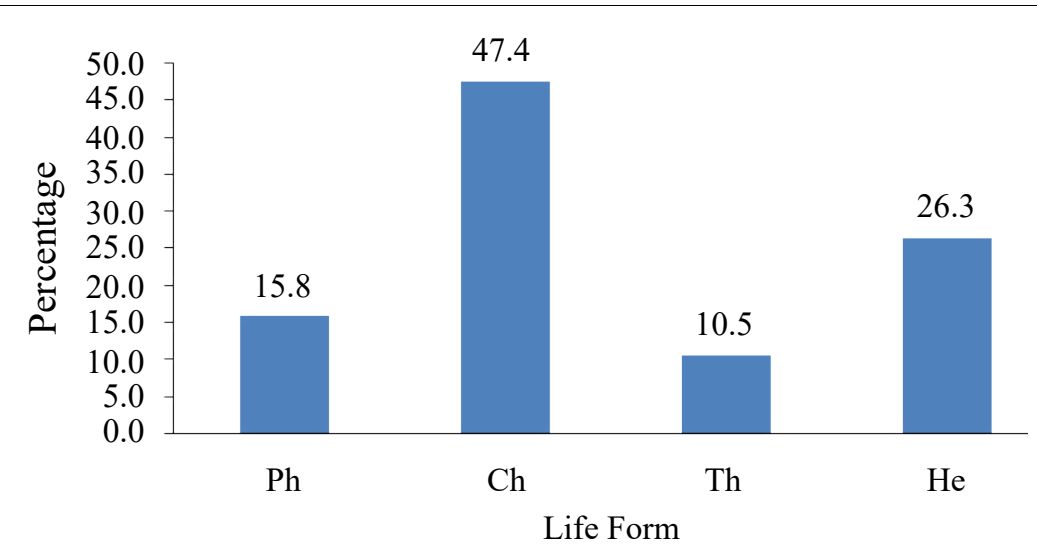

Figure 6: Life forms of Al Rayn region of Saudi Arabia species.

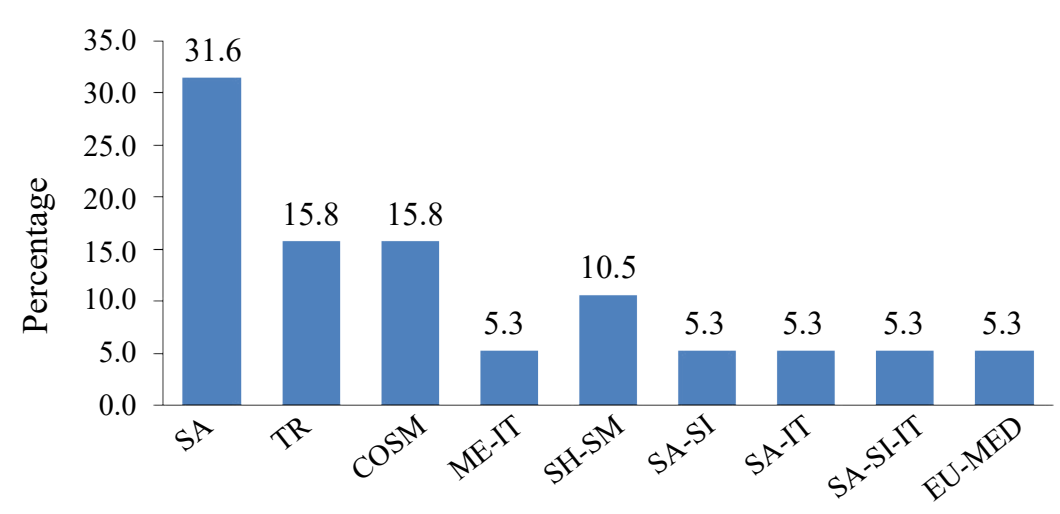

Chorotypes

Figure 7: Chorotypes of Al Rayn region of Saudi Arabia species. 
Table 3: Comparison of the soil variables or properties of the four plant communities.

\begin{tabular}{|l|c|c|c|c|c|c|}
\hline Factors & $\mathbf{I}$ & $\mathbf{I I}$ & $\mathbf{I I I}$ & $\mathbf{I V}$ & F value & P value \\
\hline Sand & 46.3 & 78.3 & 65.3 & 76.3 & 0.85 & $0.61 \mathrm{~ns}$ \\
\hline Clay & 23.7 & 9.68 & 21.1 & 13.9 & 0.14 & $0.88 \mathrm{~ns}$ \\
\hline Silt & 30 & 12 & 13.6 & 9.71 & 3.61 & $0.34 \mathrm{~ns}$ \\
\hline $\mathbf{P H}$ & 7.27 & 7.94 & 7.27 & 7.28 & 0.32 & $0.78 \mathrm{~ns}$ \\
\hline $\mathbf{E C}$ & 1.6 & 1.2 & 1.2 & 1.1 & 5.40 & $0.29 \mathrm{~ns}$ \\
\hline $\mathbf{C a}$ & 12.5 & 10.2 & 12.1 & 12.3 & 0.25 & $0.82 \mathrm{~ns}$ \\
\hline $\mathbf{M g}$ & 6.0 & 6.0 & 6.0 & 7.0 & 7.0 & $0.26 \mathrm{~ns}$ \\
\hline $\mathbf{N a}$ & 0.7 & 1.0 & 0.7 & 0.5 & 2.10 & $0.44 \mathrm{~ns}$ \\
\hline $\mathbf{K}$ & 0.8 & 0.5 & 0.9 & 0.6 & 0.5 & $0.55 \mathrm{~ns}$ \\
\hline $\mathbf{H C O}$ & 1.9 & 3.8 & 2.2 & 2.7 & 0.11 & $0.91 \mathrm{~ns}$ \\
\hline $\mathbf{C l}_{3}$ & 3.2 & 1.6 & 3.0 & 1.4 & 0.09 & $0.92 \mathrm{~ns}$ \\
\hline $\mathbf{O M}_{\mathbf{M}}$ & 0.7 & 0.25 & 0.25 & 0.29 & 8.1 & $0.24 \mathrm{~ns}$ \\
\hline $\mathbf{C a C O}_{\mathbf{3}}$ & 8.78 & 8.1 & 9.95 & 10.9 & 3.43 & $0.36 \mathrm{~ns}$ \\
\hline
\end{tabular}

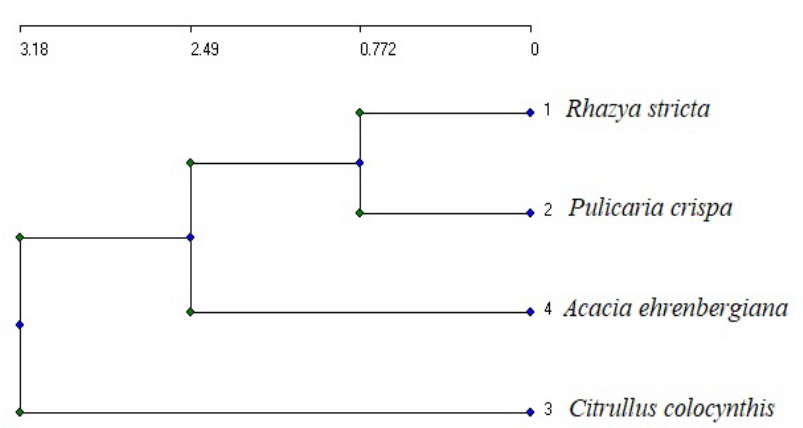

Figure 8: Hierarchical clustering analysis of the vegetation at the studied region.

dominated one was Senna italica with value (84.3). The annual species were Argemoneochroleuca, Aegilopusperegrina and Fagoniaschweinfurthii (Table 2). This community is widely spread on wide hard Sandy.

Citrullus colocynthis community: was characterized by ten plant species (seven perennials and three annuals). Citrullus colocynthis was the highest with value (103) and the codominated one was Calotropis procera with value (84.3). The annual species were Xanthium pungens, Erysimum repandum and Chenopodium glaucum (Table 2). This community occurs on sandy soils.

Acacia ehrenbergiana community: was characterized by six plant species (five perennials and one annual). Acacia ehrenbergiana was the highest with value (145.6) and the codominated one was Stipagrostisdrarii with value (63.4). The annual species was Solanumnigrum (Table 2). This community occurs on a rocky hillside.

\section{Plant Community-Soil Relationship}

Rhyzastricta community occurs on a loamy soil with sand percent $(46.3 \%)$ and clay (30\%). The plant cover percentage is about $35 \%$ on fine-textured sandy soil (Table 3 ). In addition, it is characterized by the highest contents of EC, O.M, $\mathrm{CaCO}_{3^{\prime}}$ $\mathrm{Na}, \mathrm{Mg}, \mathrm{Ca}, \mathrm{Cl}$ and the lowest of $\mathrm{pH}$ and $\mathrm{HCO}_{3}$. Pulicariacrispa community occurs on a sand loamy soil with sand percent $(78.3 \%)$ and clay (9.68 \%). In addition, it is characterized by the highest contents of $\mathrm{HCO}_{3}$ and $\mathrm{pH}$, while the lowest of $\mathrm{Ca}$, $\mathrm{K}$ and O.M. Citrulluscolocynthis community occurs on a sand loamy soil with sand percent (65.3\%) and clay (13.9\%). In addition, it is characterized by the highest contents of $\mathrm{CaCO}_{3}$ and $\mathrm{K}$, while the lowest of $\mathrm{pH}$ and O.M. Acacia ehrenbergiana community occurs on a sand loamy soil with sand percent (76.3\%) and clay (9.68 \%). In addition, it is characterized by the highest contents of $\mathrm{Mg}$, while the lowest of $\mathrm{Cl}$ (Table 3 ).The absence of a strong and clear difference between the soil elements due to the similarity of the topography in the study area.

\section{Discussion}

Saudi Arabia covers a vast area of the Arabian Peninsula and different environments and climates characterize it. Climate factors and soil characteristics are the most important determinants affecting the identification of species and growing plant communities in any region. The overall picture of vegetation in the study area is undoubtedly the result of Natural factors come in the forefront of climate (Migahid, 1996) [17]. Asteraceae, Poaceae, Fabaceae and Brassicaceae were the most common plant families in this study. Meanwhile, eight families were noted by only one species. These results were in accordance with (Collenette1999 [16]; Al-Nafie 2004 [3]; Moawed and Ansari 2015) [24]. It is worth mentioning that many of the plants that belong to these plant families are characteristic feature of desert zones (Batanouny and Baeshain 1983) [25]. In addition to, many families were recorded with only one species per families. This may be due to the fact that few of these plant species have the ability to cope and adapt with the difficult conditions in these areas (Al-Nafie 2008 [15]; El-Ghanim, et al. 2010 [26]; Al-Sherif, et al. 2013) [27]. Topography and landform and soil texture are the most important factors to determined plant life forms (AlFarhan, et al. 2005 [28]; Deenik and Yost 2006 [29]; Shaltout, et al. 2010 [30]; Alatar, et al. 2012) [31]. In this study, chamaephytes was the most abundant life formin accordance with (Al-Sherif, et al. 2013 [27]; Al-Sodany, et al. 2013[32]; Seraj, et al. 2014 [33]; Moawed and Ansari 2015 [24]; Osman, et al. 2019) [34]. The dominance of chamaephytes more than other life forms in deserts and semi-desert habitats because of several reasons as topography, biotic influence and dry climate (Zahran 1982 [35] ; Alshammari and Sharawy 2004) [36].

In Saudi Arabia (Mady1996 [13]; El-Ghanim 2000) [14] recognized several plant associations, some of which are comparable to those of the present study (e.g Acacia ehrenbergiana and Rhyzastricta which is comparable to that identified in neighboring countries (El-Bana and Al-Mathnani 2009 [37]; Shaltout, et al. 2010) [30]. The different types of communities in Al Rayn region are governed mainly by habitat factors and moisture availability. The vegetation of Al Rayn region this study fell into four different vegetation communities dominated by Rhyzastricta, Pulicariacrispa, Citrulluscolocynthis and Acacia ehrenbergiana.

\section{References}

1. Al-Shareef AS (2002) Geography of Saudi Arabia. Riyadh, Dar AlMareekh. 
2. Miller AG, Cope TA (1996) Flora of the Arabian Peninsula and Socotra. ( $1^{\text {st }}$ edn), Edinburgh University Press, Edinburgh, 1-30.

3. Al-Nafie AH (2004) Botanical Geography of Saudi Arabia. King Fahd National Library, El-Riyadh, Saudi Arabia.

4. Fadl MA, Farrag HF, Al-Sherif EA (2015) Floristic composition and vegetation analysis of wild legumes in Taif district, Saudi Arabia. International Research Journal of Agricultural Science and Soil Science 5: 74-80.

5. Zohary M (1957) A contribution to the flora of Saudi Arabia. Botanical Journal of the Linnean Society 55: 632-643.

6. Migahid AM (1978) Flora of Saudi Arabia. Riyadh University, Riyadh, Saudi Arabia.

7. Chaudhary S (2001) Flora the Kingdom of Saudi Arabia Illustrated. National herbarium ministry of agriculture and water Kingdom of Saudi Arabia. Riyadh. Saudi Arabia 2: 1-542.

8. Chaudhary S, Al-Jowaid A (2013) Vegetation of the Kingdom of Saudi Arabia. National agriculture and water research center ministry of agriculture and water kingdom of Saudi Arabia. Riyadh, Saudi Arabia, 1: 1-680.

9. Al-Turki T, Al-Olayan H (2003) Contribution to the Flora of Saud Arabia: Hail Region. Saudi Journal of Biological Science 10: 190-221.

10. Al-Farhan A (2011) A floristic account on RaudhatKhraim Central province, Saudi Arabia. Saudi Journal of Biological Science 8: 80-87.

11. Al-Khamis HH, Al-Hemaid F, Ibrahim A (2012) Diversity of Perennial Plants at Ibex Reseve in Saudi Arabia. Journal of Animal Plant Science 22: 484-492.

12. Mossa JS (1987) Medicinal plants of Saudi Arabia. King Saud University Press, Riyadh, Saudi Arabia.

13. Shaltout KH, Mady MA (1996) Analysis of Roudhas vegetation in central Saudi Arabia. Journal of Arid Environment 34: 441-454.

14. Al-Ghanim, WM (2002) Comparative Ecological Studies on the Natural Vegetation of Three Different Transects Within ElRiyadh Region. PhD Thesis, Girls College of Education, Ministry of Higher Education, Riyadh Saudi Arabia.

15. Al-Nafie AH (2008) Phytogeography of Saudi Arabia. Saud Journal of Biological Sciences 15: 159-176.

16. Collenette S (1999) Wild flowers of Saudi Arabia. King of Saudi Arabia: National Commission for Wild Life Conservation and Development (NCWCD) \& Sheila Collenette, King Fahd National Library, Kingdom of Saudi Arabia, 799.

17. Migahid AM (1996) Flora of Saudi Arabia. King Saud University Press, Riyadh.

18. Braun-Blonquet J (1965) Plant Sociology: The study of plant communities. Hafner, London, Germany. 439.

19. Raunkiaer C, Humphrey Gilbert-Carter (1937) Plant Life Form. Clarendon, Oxford.

20. Govaerts R, Frodin DG, Radcliffe-Smith A, et al. (2000) World checklist and bibliography of Euphorbiaceae (with Pandaceae). Royal Botanic Gardens, Kew 1621.

21. Wickens GE (1978) The flora of Jebel Marra (Sudan Republic) and its geographical affinities. Kew Bull 368.
22. Allen SE, Grimshaw HM, Parkinson JA, et al. (1989) Chemical Analysis of Ecological Materials. (2 $\left.{ }^{\text {nd }} E d n\right)$, Blackwell Scientific Publications, Oxford and London.

23. Ryan J, Garabet S, Harmson K, et al. (2001) Soil and Plant Analysis Laboratory Manual. ( $2^{\text {nd }}$ edn) Jointly published by the International Center for Agricultural Research in the Dry Areas (ICARDA) and the National Agricultural Research Center (NARC), Aleppo, Syria, 172.

24. Moawed MM, Ansari AA (2015) Wild plants diversity of Red Sea coastal region, Tabuk, Saudi Arabia. Journal of Chemical and Pharmaceutical Research, 7: 220-227.

25. Batanouny KH, Baeshain NA (1983) Plant communities along the Medina-Badr road across the Hijaz Mountains, Saudi Arabia. Vegetatio 53: 33-43.

26. El-Ghanim W, Hassan L, Galal T, Badr A (2010) Floristic composition and vegetation analysis in Hail region north of central Saudi Arabia. Saudi Journal of Biological Sciences 17: 119-128.

27. Al-Sherif E, Ayesh, A, Rawi S (2013) Floristic composition, life form and chorology of plant life at Khulais region, Western Saudi Arabia. Pakistan Journal of Botany 45: 29-38.

28. Al-Farhan A, Al-Turki TA, Basahy RA (2005) Flora of Jizan Region, Final Report of project AR-17-7. King Abdulaziz City for Science and Technology (KACST), KSA, 1: 1-545.

29. Deenik JL, Yost RS (2006) Chemical properties of atoll soils in the Marshall Islands and constraints to crop production. Geoderma, 136: 666-681.

30. Shaltout K, Sheded M, Salem Al (2010) Vegetation spatial heterogeneity in a hyper arid Biosphere Reserve area in North Africa. Acta Botanica Croatica 69: 31-46.

31. Alatar A, El-Sheikh MA, Thomas J (2012) Vegetation analysis of Wadi Al-Jufair, a hyper-arid region in Najd, Saudi Arabia. Saudi Journal of Biological Sciences 19: 357-368.

32. Al-Sodany YM, Bazaid SA, Mosallam HA (2013) Medicinal plants in Saudi Arabia: I. Sarrwat Mountains at Taif, KSA. Academic Journal of Plant Sciences 6: 134-145.

33. Seraj SS, Jrais RN, Ayyad SK (2014) Floristic Composition, Life Form and Chorology of Plant Life at Al-Saoda, Asir Region, South-Western Saudi Arabia. Journal of Biology, Agriculture and Healthcare, 4: 60-65.

34. Osman AKE, Abdein MAEH (2019) Floristic diversity of Wadi Ar'ar, Saudi Arabia. Journal of Taibah University for Science 13: 772-789.

35. Zahran M (1982) Vegetation types of Saudi Arabia. Faculty of Meteorology and Arid Environment, King Abdulaziz University press. Jeddah, 61 .

36. Alshammari AM, Sharawy SM (2004) Wild plants diversity of the Hema Faid region (Ha'il Province, Saudi Arabia). Asian J Plant Sciences 9: 447-454.

37. El-Bana MI, Al-Mathnani AS (2009) Vegetation-soil relationships in the Wadi Al-Hayat area of the Libyan Sahara. Australian J Basic and Applied Science 3: 740-747.

DOI: $10.36959 / 742 / 239$

Copyright: (C) 2021 Alzamel NM. This is an open-access article distributed under the terms of the Creative Commons Attribution License, which permits unrestricted use, distribution, and reproduction in any medium, provided the original author and source are credited. 